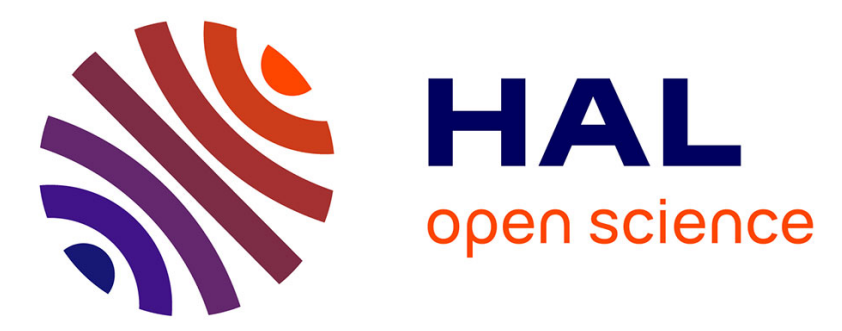

\title{
The degree of mineralization is a determinant of bone strength: a study on human calcanei.
}

\author{
Hélène Follet, Georges Boivin, C. Rumelhart, Pierre J. Meunier
}

\section{To cite this version:}

Hélène Follet, Georges Boivin, C. Rumelhart, Pierre J. Meunier. The degree of mineralization is a determinant of bone strength: a study on human calcanei.. BONE, 2004, 34 (5), pp.783-9. 10.1016/j.bone.2003.12.012 . inserm-00557244

\section{HAL Id: inserm-00557244 https://www.hal.inserm.fr/inserm-00557244}

Submitted on 15 Jun 2011

HAL is a multi-disciplinary open access archive for the deposit and dissemination of scientific research documents, whether they are published or not. The documents may come from teaching and research institutions in France or abroad, or from public or private research centers.
L'archive ouverte pluridisciplinaire HAL, est destinée au dépôt et à la diffusion de documents scientifiques de niveau recherche, publiés ou non, émanant des établissements d'enseignement et de recherche français ou étrangers, des laboratoires publics ou privés. 


\title{
The degree of mineralization is a determinant of bone strength: a study on human calcanei
}

\author{
H. Follet, ${ }^{a}$ G. Boivin, ${ }^{\text {b,* }}$ C. Rumelhart, ${ }^{\mathrm{a}}$ and P.J. Meunier ${ }^{\mathrm{b}}$

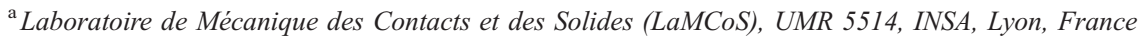 \\ ${ }^{\mathrm{b}}$ INSERM Unité 403, Faculté de Médecine R. Laennec, Université Claude Bernard-Lyon1, Lyon, France
}

Received 21 July 2003; revised 1 November 2003; accepted 17 December 2003

\begin{abstract}
Strength of bones depends on bone matrix volume (BMV), bone microarchitecture, and also on the degree of mineralization of bone (DMB). We have recently shown in osteoporotic patients treated with alendronate that fracture risk decreased and bone mineral density increased with a parallel increase of the DMB due to prolonged secondary mineralization but without modifications of BMV or bone microarchitecture. DMB and strength were both measured at the tissue level in calcaneus bone samples taken at autopsy from 20 subjects (aged $78 \pm 8$ years, 8 women, 12 men) who died suddenly without apparent bone disease. DMB parameters measured on microradiographs (mean $\mathrm{DMB}$, distribution of DMB, most frequent maximum DMB value, and width at half maximum, an index reflecting the homogeneity of DMB) were compared with those reported in iliac cancellous bone samples of 43 human bones. Histomorphometric measurements of microarchitectural parameters ( $\mathrm{TbTh}, \mathrm{TbN}$, and $\mathrm{TbSp}$ ) were also measured. Compression tests were performed on contiguous samples of the same calcaneus on a universal screw-driven machine (Schenck RSA 250). A 5000-N load cell (TME, F 501 TC) measured the compressive load. The displacement was measured directly on the sample using a specific displacement transducer developed by the «Laboratoire de Mécanique des Contacts et des Solides (LaMCoS).» The apparent Young's modulus (E), the maximal strength $\left(\sigma_{\max }\right)$, and the work $(\mathrm{W})$ until failure were measured. In human cancellous bone tissue, mean DMB $( \pm \mathrm{SD})$ was higher in calcaneus $\left(1.135 \pm 0.147 \mathrm{~g} / \mathrm{cm}^{3}\right)$ than in iliac crest $\left(1.098 \pm 0.077 \mathrm{~g} / \mathrm{cm}^{3}\right)$. The mean most frequent maximum DMB values (mean DMB freq. max.) were $1.118 \pm 0.175 \mathrm{~g} / \mathrm{cm}^{3}$ in calcaneus and $1.108 \pm 0.095 \mathrm{~g} / \mathrm{cm}^{3}$ in iliac samples, and DMB was more heterogeneous in calcaneus than in iliac samples (mean width at half maximum were $0.270 \pm 0.127$ versus $0.227 \pm 0.056 \mathrm{~g} / \mathrm{cm}^{3}$, respectively). Compression tests revealed significant positive linear correlations between DMB and both elastic modulus $\left(r^{2}=0.69\right)$ and maximal strength $\left(r^{2}=0.69\right)$. Correlations with DMB persisted $(P<0.003)$ even after adjustment for both calcified bone volume, for the Young's modulus (E), the maximal strength $\left(\sigma_{\max }\right)\left(r^{2}=0.44\right.$ and 0.41 , respectively), and microarchitectural parameters $\left(0.50<r^{2}<0.56, P<0.001\right)$. The same results were obtained with the work to fracture $(\mathrm{W})\left(0.23<r^{2}<0.46, P<\right.$ $0.045)$. We conclude that the more the cancellous tissue was mineralized, the higher was its stiffness and compressive strength. This may explain the increase in bone strength when DMB is modified in a physiological range without necessary changes of BMV and bone microarchitecture. The impact of such modifications on fracture risk and the therapeutic implications of these data remain to be analyzed.

(C) 2003 Elsevier Inc. All rights reserved.
\end{abstract}

Keywords: Degree of mineralization; Quantitative microradiography; Cancellous bone; Compressive test; Calcaneus

\section{Introduction}

Bone strength is determined not only by the volume of bone tissue and the microarchitectural organization of this bone, but also by the degree of mineralization of bone (DMB)

* Corresponding author. INSERM Unité 403, Faculté de Médecine R. Laennec, Université Claude Bernard-Lyon1, 69372 Lyon Cedex 08, France. Fax: +33-4-78-77-86-63.

E-mail addresses: hefollet@iupui.edu (H. Follet), boivin@laennec.univ-lyon1.fr (G. Boivin), rumelhar@insa-lyon.fr (C. Rumelhart), pierre.meunier@laennec.univ-lyon1.fr (P.J. Meunier). matrix $[2,4,5,7,21]$. The mineralization process consists of a primary deposition of mineral substance on the calcification front, followed by a slow and progressive increase in mineral deposition called secondary mineralization.

From microradiographic observations made in the 1970s, it is clear that the DMB varies between and within basic structural units (BSUs), namely, osteons in cortical bone and trabecular packets in cancellous bone; recently deposited BSUs being much less mineralized than the older ones. The «young» ones appear dark grey in microradiographs, whereas «old» ones are whiter (Fig. 1). This heterogeneity in the $\mathrm{DMB}$ is explained by the fact that bone formation, which 


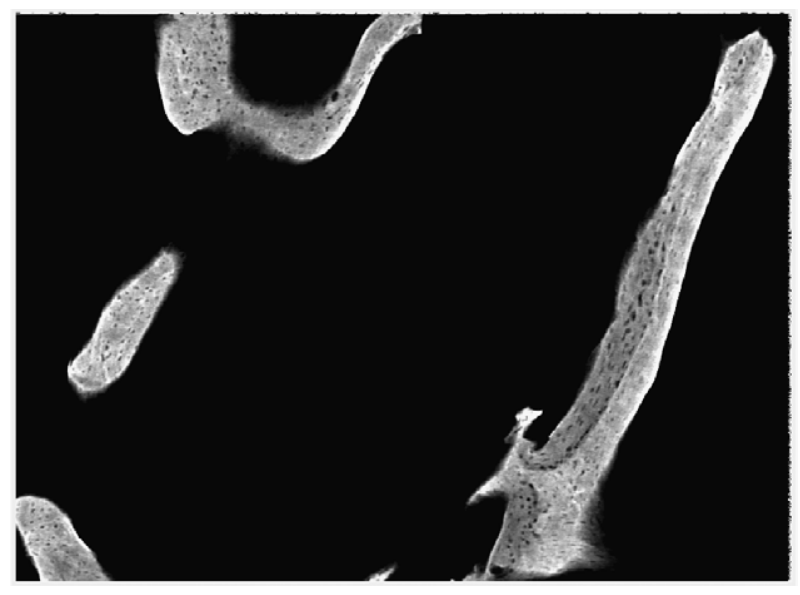

Fig. 1. Calcaneus cancellous bone microradiograph illustrating the heterogeneity in the degree of mineralization of different BSUs.

follows bone resorption in the remodeling sequence, is a multistep process. Following its deposition, the new matrix begins to mineralize after about 5-10 days, and the linear rate of this primary mineralization can be measured directly in vivo using double tetracycline labeling. After full deposition (completion) of the BSU, a long phase of secondary mineralization begins. In adult bone, the DMB depends on the rate of remodeling [21], which is the main biological determinant of the degree of mineralization [5]. In osteoporosis, where there is a negative imbalance between bone resorption and bone formation, therapeutics agents for

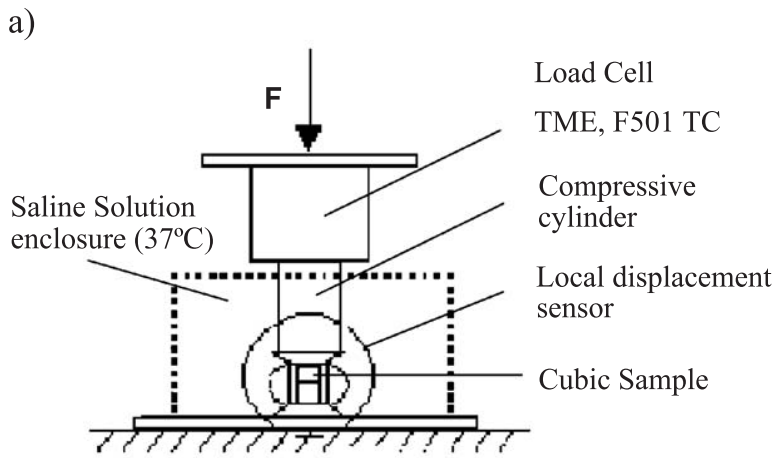

b)

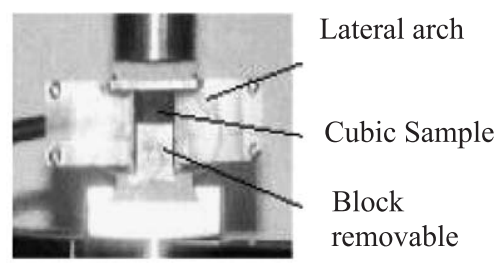

Fig. 3. Description of the equipment used for compressive tests. (a) Plan, (b) local displacement transducer.

osteoporosis could increase bone strength through their effects on bone mass, microarchitecture, and the DMB [7].

To date, although the relationships between the mechanical properties of bone and either bone mass or microarchitecture parameters of bone have been investigated in

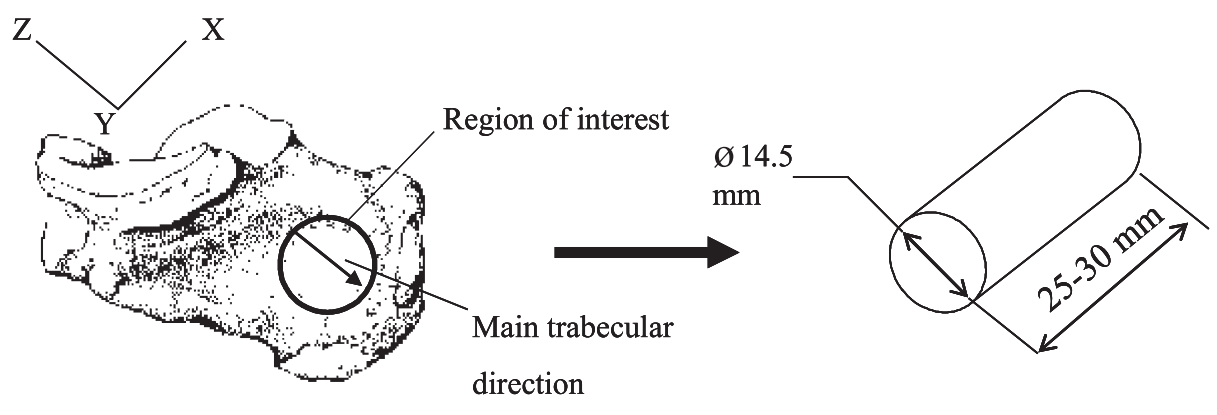

Medial view (right Calcaneus)

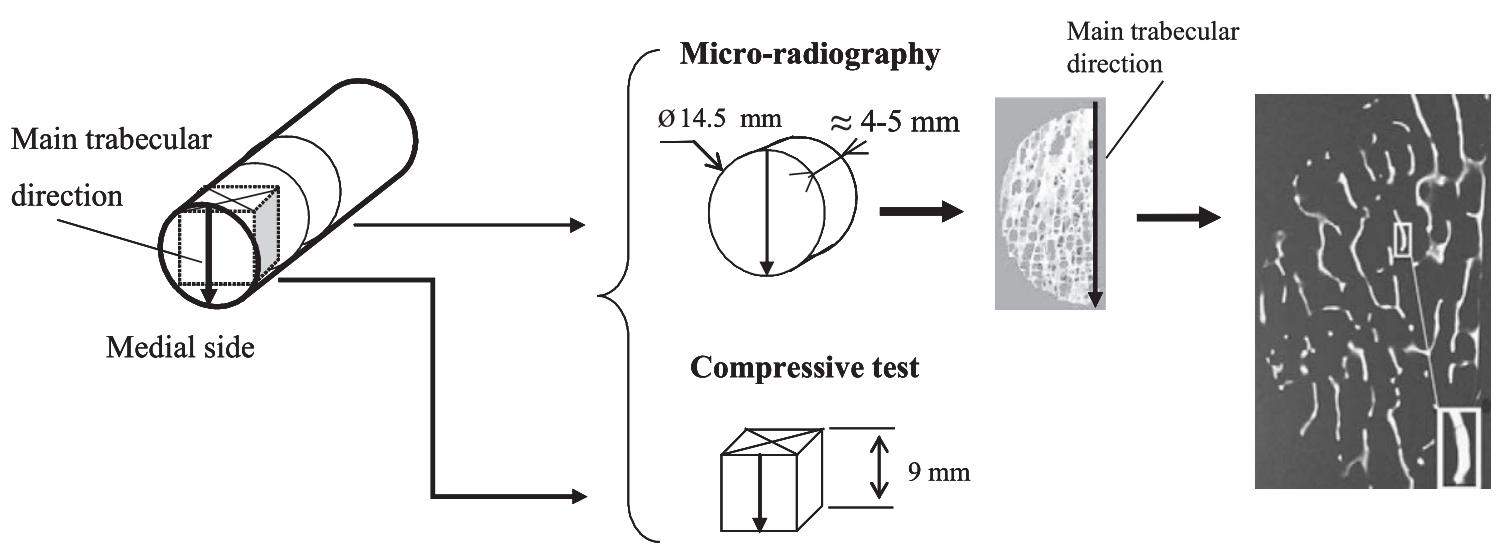

Fig. 2. Preparation of the samples taken from human calcaneus. 


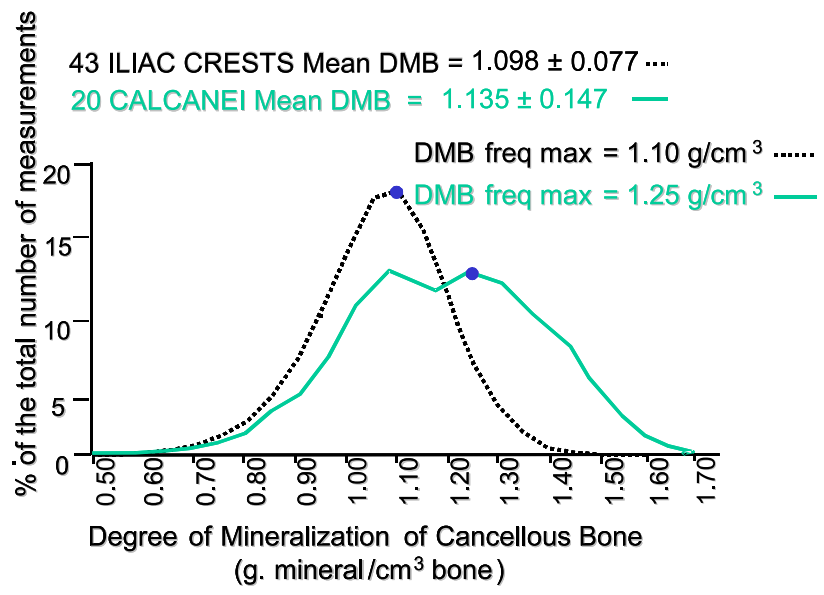

Fig. 4. Comparison of the global distributions of the degree of mineralization measured in iliac and calcaneus samples from two different human populations. Mean DMB of calcanei is significantly higher $(P<$ $0.01)$ than that measured in iliac crests.

several studies $[10,16]$, the influence of the degree of mineralization on bone strength has not been tested. The aim of this study was to analyze the relationship between the $\mathrm{DMB}$ and the mechanical properties of cancellous bone samples taken from the human calcaneus. We used compressive testing on cubic samples of cancellous bone as recommended by Linde et al. $[19,20]$ as a biomechanical test.

\section{Materials and methods}

Twenty fresh calcanei excised from subjects aged $78 \pm$ 8 years (range 61-91 years: 8 women, 12 men) were used in this study. After radiographs were taken in the lateral direction, a core was drilled in the posterior body of the calcaneus. One cubic sample (medial, $9 \mathrm{~mm} / \mathrm{side}$ ) and one cylindric sample (center, $14.5 \mathrm{~mm}$ diameter) oriented in the main trabecular direction (direction $\mathrm{Z}$ ) were cut from the original core (Fig. 2). The cubic sample was subjected to compressive testing in the $\mathrm{Z}$ direction. The cubic samples were stored at $-20^{\circ} \mathrm{C}$ before testing. Before mechanical testing, samples were put in preserving solution $(50 \%$ ethanol, $50 \%$ saline solution) at $+4{ }^{\circ} \mathrm{C}$ for $3-4$ days and then kept at ambient temperature for $4 \mathrm{~h}$, as recommended by other investigators $[19,20]$. The cylindrical sample was cut into two equals parts, one part was embedded in methyl methacrylate to measure the DMB and the other part was used for other studies.

Compressive tests were performed in the main trabecular direction using an universal screw-driven machine (Schenck RSA 250) equipped with a 5000-N load cell (TME, F 501 $\mathrm{TC}$, resolution $0.1 \%$ ) and a local displacement transducer (Fig. 3) developed by the Laboratoire de Mécanique des Contacts et des Solides (LaMCoS; INSA, Lyon, France) [22]. Cubic samples were kept in saline solution $\left(37^{\circ} \mathrm{C}\right)$ by a temperature governor (Ministat, Huber ${ }^{\circledR}$ ) to be as near as possible to in vivo conditions. The apparent Young's modulus (E), the maximal strength $\left(\sigma_{\max }\right)$, and the work to fracture (W) until failure were measured in the main trabecular direction [26].

The DMB was measured at the cancellous level by a computerized quantitative contact microradiography method $[2,4,18,21]$. This technique allows us to quantify the amount of mineral substance contained in a unit volume of tissue matrix. Undecalcified calcaneus samples were fixed in $80 \%$ alcohol, dehydrated in absolute alcohol, and then embedded in methyl methacrylate [6]. The bone samples were first cut into thick slices (about $150 \mu \mathrm{m}$ thick), ground manually to the precise thickness of $100 \pm 1 \mu \mathrm{m}$ then microradiographed $[2,4,5,7,17,21]$. Microradiographs were performed on sections in which the main trabecular direction was determined from X-rays before drilling the bone (Fig. 2). Contact microradiography was performed on one slice using an Xray diffraction unit PW 1830/40 equipped with a diffraction tube PW 2273/20 (Philips, Limeuil Brévannes, France). The nickel-filtered copper K $\alpha$ radiation was used under $25 \mathrm{kV}$ and $25 \mathrm{~mA}$. For quantitative evaluation of the X-ray absorption by the bone section, a reference system composed of aluminum, was exposed on each microradiograph. The DMB was quantified using a new combined contact microradiography microdensitometry-computerized method [4]. After calibration using the aluminum reference step wedge, the measured

Table 1

Descriptive statistics of 20 calcanei with mean DMB: mean degree of mineralization of all measurement points; DMB: mean of individual means of the degree of mineralization; calcified BV/TV: calcified bone volume; TbTh: trabecular thickness; TbN: trabecular number; TbSp: trabecular separation; W: work to fracture; E: apparent Young's modulus; and $\sigma_{\max }$ : maximal strength

\begin{tabular}{|c|c|c|c|c|c|c|c|c|c|}
\hline & $\begin{array}{l}\text { Mean DMB } \\
\left(\mathrm{g} \text { mineral } / \mathrm{cm}^{3}\right)\end{array}$ & $\begin{array}{l}\text { DMB } \\
\left(\mathrm{g} \text { mineral } / \mathrm{cm}^{3}\right)\end{array}$ & $\begin{array}{l}\text { Calcified } \\
\text { BV/TV (\%) }\end{array}$ & $\begin{array}{l}\text { TbTh } \\
(\mu \mathrm{m})\end{array}$ & $\begin{array}{l}\mathrm{TbN} \\
\left(\mathrm{mm}^{-1}\right)\end{array}$ & $\begin{array}{l}\text { TbSp } \\
(\mu \mathrm{m})\end{array}$ & $\begin{array}{l}\mathrm{W} \\
\left(\mathrm{kJ} / \mathrm{m}^{3}\right)\end{array}$ & $\begin{array}{l}\mathrm{E} \\
(\mathrm{MPa})\end{array}$ & $\begin{array}{l}\sigma_{\max }^{\mathrm{a}} \\
(\mathrm{MPa})\end{array}$ \\
\hline$n$ & $35104^{b}$ & 20 & 20 & 20 & 20 & 20 & 19 & 20 & 18 \\
\hline Mean & 1.226 & 1.135 & 15.47 & 155.27 & 0.971 & 944 & 43 & 368 & 3.89 \\
\hline Median & - & 1.132 & 14.23 & 152.0 & 0.990 & 872 & 38 & 304 & 3.54 \\
\hline SD & 0.125 & 0.147 & 6.08 & 33.10 & 0.238 & 333 & 34 & 338 & 2.94 \\
\hline Minimum & 0.551 & 0.905 & 5.74 & 113.32 & 0.490 & 503 & 3 & 19 & 0.28 \\
\hline Maximum & 1.799 & 1.427 & 27.25 & 245.43 & 1.450 & 1922 & 118 & 1257 & 11.61 \\
\hline
\end{tabular}

\footnotetext{
${ }^{a}$ Two results have not been obtained for technical reason.
}

${ }^{\mathrm{b}}$ Number of measurements. 
Table 2

Correlations among degree of mineralization (DMB), work to fracture $(\mathrm{W})$, apparent Young's modulus $(\mathrm{E})$, maximal strength $\left(\sigma_{\text {max }}\right)$, and calcified bone volume (calcified $\mathrm{BV} / \mathrm{TV}$ ) in cancellous calcaneus bone

\begin{tabular}{|c|c|c|c|c|c|c|c|c|}
\hline \multirow{3}{*}{$n$} & \multicolumn{2}{|c|}{$\mathrm{DMB}\left(\mathrm{g}\right.$ mineral $\left./ \mathrm{cm}^{3}\right)$} & \multicolumn{2}{|c|}{$\sqrt{E}(\mathrm{MPa})$} & \multicolumn{2}{|c|}{$\sigma_{\max }(\mathrm{MPa})$} & \multicolumn{2}{|c|}{ Calcified BV/TV (\%) } \\
\hline & \multicolumn{2}{|l|}{20} & \multicolumn{2}{|l|}{20} & \multicolumn{2}{|l|}{18} & \multicolumn{2}{|l|}{20} \\
\hline & $\overline{r^{2}}$ & $P$ & $\overline{r^{2}}$ & $P$ & $\overline{r^{2}}$ & $P$ & $\overline{r^{2}}$ & $P$ \\
\hline$\overline{\sqrt{W}}\left(\mathrm{~kJ} / \mathrm{m}^{3}\right)$ & 0.43 & 0.002 & 0.52 & 0.001 & 0.75 & 0.000 & 0.24 & 0.035 \\
\hline DMB & - & - & 0.69 & 0.0000 & 0.69 & 0.0000 & 0.49 & 0.0003 \\
\hline$\sqrt{E}$ & - & - & - & - & 0.91 & 0.0000 & 0.49 & 0.0000 \\
\hline$\sigma_{\max }$ & - & - & - & - & - & - & 0.55 & 0.0000 \\
\hline
\end{tabular}

area was automatically selected and the gray levels were measured from the computer-generated map indicating the spatial distribution of the «measurement units.» The DMB was finally expressed in $\mathrm{g}$ mineral $/ \mathrm{cm}^{3}$ bone. The main parameters used in the description of the mineralization of bone (Fig. 4) are the mean DMB and the distribution of DMB. From the individual curves showing the distribution of DMB, the most frequent highest DMB values (DMB freq. max.) and the full widths at half maximum (half height), an index reflecting the heterogeneity of DMB, were also calculated [5]. For the correlations, the mean of individual means of the DMB were used.

For comparison, iliac crest bone samples $[4,5]$ were taken at autopsy from 43 subjects (30 women aged $48.4 \pm 3.7$ years, range $20-93$ years, and 13 men aged $66 \pm 4.4$ years, range $43-86$ years). This group was studied as a whole, that is, 43 persons (aged $53.7 \pm 3.2$ years, range $20-93$ years). In this whole group, the mean degree of mineralization expressed in $\mathrm{g}$ mineral $/ \mathrm{cm}^{3}$ (mean $\pm \mathrm{SD}$ ) was $1.098 \pm$ 0.077 in cancellous bone. No structural parameters were measured on these samples. The iliac crests and calcanei came from two different populations.

Histomorphometric parameters measured on microradiographs like calcified bone volume, representing the percentage of spongy bone tissue occupied by mineralized bone (calcified BV/TV in \%), and microarchitectural parameters such as trabecular thickness ( $\mathrm{TbTh}$ in $\mu \mathrm{m}$ ), trabecular number $\left(\mathrm{TbN}\right.$ in $\mathrm{mm}^{-1}$ ), and trabecular separation $(\mathrm{TbSp}$ in $\mu \mathrm{m})$ were also measured in our calcanei samples $[11,23]$.

Descriptive statistics were summarized by mean value, standard deviation, and range. To obtain a normal distribution, the apparent Young's modulus (E) and the work to fracture $(\mathrm{W})$ were transformed by square root transformation and the trabecular separation (TbSp) was transformed by logarithmic transformation (Shapiro-Wilk normality test). The relationships between normally distributed parameters were evaluated by Pearson correlation coefficients. Partial correlation was used to obtain the linear correlation between two variables after the effects of some other variables had been filtered out (adjustment for calcified bone volume parameter in \%). Significance was set at $P \leq 0.05$ for all parameters.

\section{Results}

In human cancellous bone tissue (Fig. 4), mean DMB ( \pm SD) was significantly higher $(P<0.01)$ in the calcaneus $\left(1.135 \pm 0.147 \mathrm{~g} / \mathrm{cm}^{3}\right.$, range from 0.551 to $\left.1.799 \mathrm{~g} / \mathrm{cm}^{3}\right)$ than in the iliac crest $\left(1.098 \pm 0.077 \mathrm{~g} / \mathrm{cm}^{3}\right.$, range from 0.506 to $1.525 \mathrm{~g} / \mathrm{cm}^{3}$ ). The mean most frequent maximum DMB values were $1.118 \pm 0.175 \mathrm{~g} / \mathrm{cm}^{3}$ in calcaneus and $1.108 \pm$ $0.095 \mathrm{~g} / \mathrm{cm}^{3}$ in iliac samples, and DMB was more heterogeneous in the calcaneus than in the iliac samples (mean widths at half maximum were $0.270 \pm 0.127$ and $0.227 \pm 0.056 \mathrm{~g} /$ $\mathrm{cm}^{3}$, respectively). When the distributions of all measurements were analyzed, the heterogeneity of DMB values (scattering of values with two peaks very closed) appeared twice as high in the calcaneus than in the iliac crest (Fig. 4).

The apparent Young's modulus (E) measured by compressive tests until failure for the 20 medial samples ranged between 19 and $1257 \mathrm{MPa}$, with a mean $( \pm \mathrm{SD})$ equal to $368 \pm 338 \mathrm{MPa}$. The maximal strength $\left(\sigma_{\max }\right)$ measured by compressive tests until failure for 18 medial samples ranged between 0.28 and $11.61 \mathrm{MPa}$, with a mean $( \pm \mathrm{SD})$ of $3.89 \pm$ $2.94 \mathrm{MPa}$. The work to fracture (area under the curve load displacement) measured by compressive tests until failure for 19 medial samples ranged between 3 and $118 \mathrm{~kJ} / \mathrm{m}^{3}$ with a

Table 3

Correlations among microarchitectural parameters ( $\mathrm{TbTh}, \mathrm{TbN}$, and $\log \mathrm{TbSp}$ ), degree of mineralization (DMB), work to fracture (W), apparent Young's modulus $(\mathrm{E})$, and maximal strength $\left(\sigma_{\max }\right)$ in calcified bone volume (calcified BV/TV)

\begin{tabular}{|c|c|c|c|c|c|c|c|c|}
\hline \multirow{3}{*}{$n$} & \multicolumn{2}{|c|}{ DMB $\left({\left.\mathrm{g} \mathrm{mineral} / \mathrm{cm}^{3}\right)}^{3}\right.$} & \multicolumn{2}{|c|}{$\sqrt{E}(\mathrm{MPa})$} & \multicolumn{2}{|c|}{$\sigma_{\max }(\mathrm{MPa})$} & \multicolumn{2}{|c|}{$\sqrt{W}\left(\mathrm{~kJ} / \mathrm{m}^{3}\right)$} \\
\hline & \multicolumn{2}{|l|}{20} & \multicolumn{2}{|l|}{20} & \multicolumn{2}{|l|}{18} & \multicolumn{2}{|l|}{19} \\
\hline & $r^{2}$ & $P$ & $r^{2}$ & $P$ & $r^{2}$ & $P$ & $r^{2}$ & $P$ \\
\hline Calcified BV/TV (\%) & 0.49 & 0.0003 & 0.49 & 0.0003 & 0.55 & 0.0002 & 0.24 & 0.035 \\
\hline $\operatorname{TbTh}(\mu \mathrm{m})$ & 0.37 & 0.0024 & 0.43 & 0.0008 & 0.38 & 0.0034 & 0.07 & 0.289 \\
\hline $\mathrm{TbN}\left(\mathrm{mm}^{-1}\right)$ & 0.36 & 0.0025 & 0.29 & 0.0067 & 0.44 & 0.0013 & 0.33 & 0.01 \\
\hline $\log \operatorname{TbSp}\left(\mathrm{mm}^{-1}\right)$ & 0.38 & 0.0020 & 0.32 & 0.0046 & 0.42 & 0.0018 & 0.26 & 0.026 \\
\hline
\end{tabular}




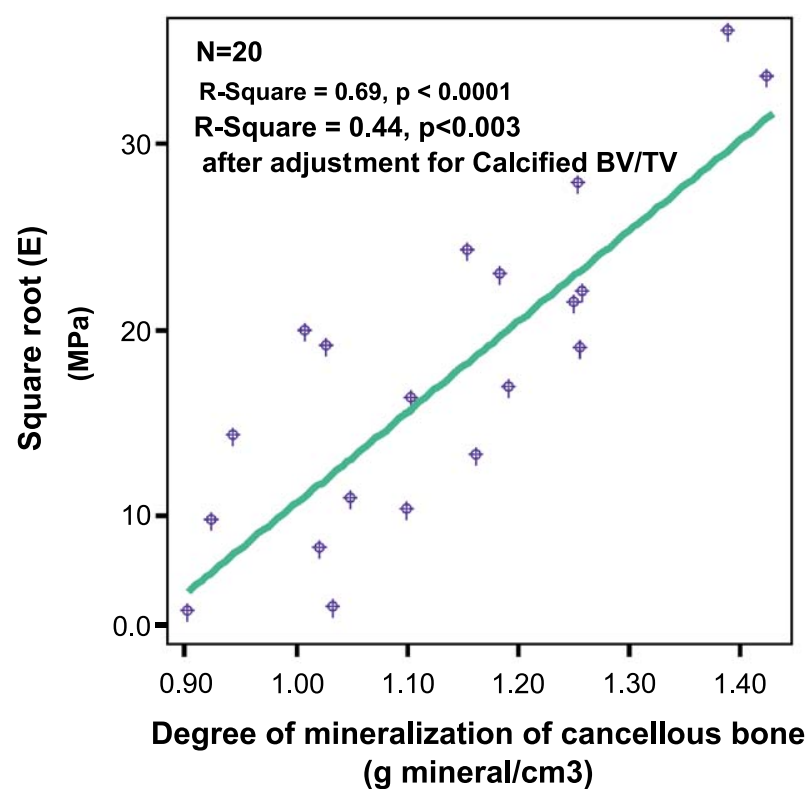

Fig. 5. Correlation between apparent Young's modulus $(\sqrt{ } E)$ and degree of mineralization of cancellous bone.

mean $( \pm \mathrm{SD})$ of $43 \pm 34 \mathrm{~kJ} / \mathrm{m}^{3}$. The calcified bone volume (calcified BV/TV) measured by microradiography for the 20 half cylindrical samples varied between $5.74 \%$ and $27.25 \%$, with a mean $( \pm \mathrm{SD})$ equal to $15.47 \% \pm 6.08 \%$. All descriptive statistics are shown in Table 1.

Correlations among DMB, Young's modulus (E), maximal strength $\left(\sigma_{\max }\right)$, and calcified $\mathrm{BV} / \mathrm{TV}$ were significant $\left(0.49<r^{2}<0.91, P<0.0003\right)$ and are shown in Table 2. The work to fracture $(\mathrm{W})$ is also significantly correlated with these parameters $\left(0.249<r^{2}<0.75, P<0.035\right.$; Table 2). Significant positive linear correlations were observed be-

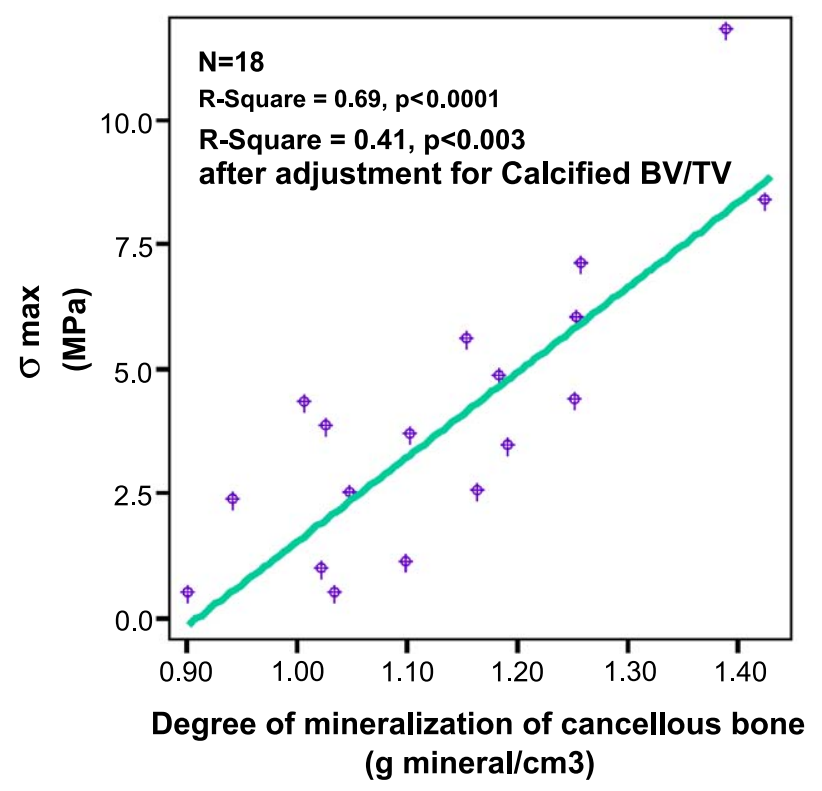

Fig. 6. Correlation between maximal strength $\left(\sigma_{\max }\right)$ and degree of mineralization of cancellous bone.
Table 4

Correlations among degree of mineralization (DMB), work to fracture (W), apparent Young's modulus (E), and maximal strength $\left(\sigma_{\max }\right)$ after adjustment for (1) calcified bone volume (calcified BV/TV), (2) trabecular thickness (TbTh), (3) trabecular number $(\mathrm{TbN})$, and (4) trabecular separation $(\log \mathrm{TbSp})$

\begin{tabular}{|c|c|c|c|}
\hline \multirow{3}{*}{$n$} & DMB $\left(\mathrm{g}\right.$ mineral $\left./ \mathrm{cm}^{3}\right)$ & $\sqrt{E}(\mathrm{MPa})$ & $\sigma_{\max }(\mathrm{MPa})$ \\
\hline & 20 & 20 & 18 \\
\hline & $r^{2}$ & $r^{2}$ & $r^{2}$ \\
\hline
\end{tabular}

(1) First order correlations controlling for calcified BV/TV (\%)

$\begin{array}{lllllll}\sqrt{W} & 0.26 & 0.032 & 0.37 & 0.008 & 0.74 & 0.0000\end{array}$

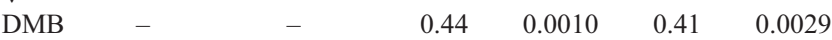

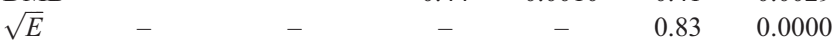

(2) First order correlations controlling for TbTh ( $\mu \mathrm{m})$

$\begin{array}{lllllll}\sqrt{W} & 0.46 & 0.003 & 0.57 & 0.0000 & 0.86 & 0.0000\end{array}$

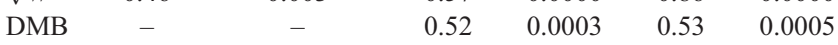

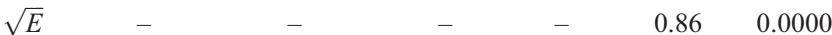

(3) First order correlations controlling for $\operatorname{TbN}(\mathrm{mm})$

$\begin{array}{lcccccl}\sqrt{W} & 0.23 & 0.045 & 0.35 & 0.010 & 0.63 & 0.000 \\ \mathrm{DMB} & - & - & 0.56 & 0.0001 & 0.50 & 0.0008 \\ \sqrt{E} & - & - & - & - & 0.89 & 0.0000\end{array}$

(4) First order correlations controlling for Log TbSp ( $\mu m)$

\begin{tabular}{lcccccl}
$\sqrt{W}$ & 0.26 & 0.032 & 0.37 & 0.008 & 0.67 & 0.000 \\
$\mathrm{DMB}$ & - & - & 0.55 & 0.0001 & 0.50 & 0.0007 \\
$\sqrt{E}$ & - & - & - & - & 0.87 & 0.0000 \\
\hline
\end{tabular}

tween two histomorphometric parameters (TbTh and TbN; Table 3) versus DMB, apparent Young's modulus (E), and maximal strength $\left(\sigma_{\max }\right)\left(0.29<r^{2}<0.44, P<0.007\right)$, respectively. The work to fracture (W) is correlated with $\mathrm{TbN}$ and TbSp $\left(r^{2}<0.33, P<0.026\right)$.

Interestingly, compression tests revealed significant positive linear correlations between DMB and both the elastic modulus $\left(r^{2}=0.69\right)$ and maximal strength $\left(r^{2}=0.69\right)$ (Figs. 5 and 6). After adjustment for calcified bone volume (calcified BV/TV), significant correlations persisted among DMB, apparent Young's modulus (E), maximal strength $\left(\sigma_{\max }\right)\left(0.41<r^{2}<0.83, P<0.003\right.$; Table 4$)$, and the work to fracture $(\mathrm{W})\left(r^{2}=0.26, P<0.032\right)$.

After adjustment for three histomorphometric parameters reflecting bone microarchitecture ( $\mathrm{TbTh}, \mathrm{TbN}$, and $\mathrm{TbSp}$ ), significant correlations persisted among DMB, the apparent Young's modulus (E), and maximal strength $\left(\sigma_{\max }\right)\left(0.50<r^{2}\right.$ $<0.56, P<0.001$; Table 4$)$. The same results are also obtained for work to fracture $\left(0.23<r^{2}<0.46, P<0.045\right.$; Table 4$)$.

\section{Discussion}

In vivo, the calcaneus is an accessible site that easily allows dual X-ray absorptiometry (DXA) and ultrasound (US) measurements. Additionally, the calcaneus is used clinically as a good predictor of risk for hip and vertebrae fracture $[15,27,28]$.

Measuring mechanical properties of cancellous bone tissue is more difficult than measuring those properties in 
cortical bone because of the extremely small dimensions of the individual trabeculae. Following Linde et al. $[19,20]$, a compressive test on a cubic sample of cancellous bone was chosen.

We have shown that the more the cancellous tissue was mineralized, the higher was its stiffness, and that young human bone is less well mineralized than mature bone. This confirms the previous studies in humans [13,14,24]. In the calcaneus, like in the iliac crest $[4,5]$, there was no significant correlation between DMB and the age of the patients (data not shown). The age of bone is given by the DMB. Significant correlations persisted between DMB and all mechanical parameters, even after adjustment for the calcified bone volume and microarchitectural parameters, showing the lack of influence of the calcified BV/TV and of structural parameters.

These results may explain the increase in bone strength when the DMB is augmented without changes in bone matrix volume (BMV) and bone microarchitecture, as was observed in ovariectomized baboons treated with alendronate [21] and in postmenopausal osteoporotic patients treated with alendronate [7]. It remains now to evaluate the impact of such modifications on fracture risk and the therapeutic implications of these data. In ovariectomized baboons treated for 2 years with alendronate, bone turnover was normalized, bone loss was prevented, and vertebral bone strength was increased to control values [1]. In the same animals, DMB also increased to normal values after treatment [21].

The values obtained in this study for mean apparent Young's modulus (E) (368 MPa) and mean maximal strength $\left(\sigma_{\max }\right)(3.89 \mathrm{MPa})$ measured by compressive tests until failure are on the same order of magnitude as those found in the literature [22,29]. Compressive testing was executed as recommended by Mitton et al. [22].

With reference to the degree of mineralization, the young human bone is less well mineralized than mature bone [4,5]. This confirms different studies in humans. In 1987, Currey [13] tested 162 specimens from 19 species of amniotes to show the various mechanical and physical properties between different groups. All mechanical properties showed high levels of variation. In 1996, Currey et al. [14] studied static toughness and changes in strength of human cortical bone with age. Reid and Boyde [24] showed that a greater bone turnover occurred in the outer cortex and suggested a differential mechanical loading across the rib.

Ciarelli et al. [12] used backscattered electron microscopy to study mineralization levels of human iliac cancellous bone of White females $(N=49)$. The data set consisted of bone biopsies from normal and vertebral fracture subjects that had either high or low values for bone formation rate. The authors hypothesized that both low and high patterns of mineralization might detrimentally affect bone material properties, with low mineralization levels causing reduced stiffness and strength and high mineralization resulting in reduced fracture toughness.
Roschger et al. [25] studied the effects of alendronate treatment on the density of mineralization, the ultrastructure of the mineral or collagen composite, the size and location of mineral particles in iliac cancellous bone, as well as the porosity of iliac cortical bone from postmenopausal osteoporotic women. The mineral structure was investigated by quantitative backscattered electron imaging and by scanning small-angle X-ray scattering. These authors found that the mineralization was significantly higher and more uniform after treatment, and they suggested that these effects may contribute to the observed reduction in fractures.

Recently, Bouxsein [8] summarized the features and characteristics that determine a bone's ability to resist fracture and using this information to identify new therapeutic targets and develop better biomarkers and noninvasive imaging modalities [8].

Comparing the iliac crest and the calcaneus, DMB values are more heterogeneously distributed in the calcaneus samples and values are shifted toward highest values. Our results show that the more the cancellous tissue was mineralized, the higher was its stiffness and compressive strength. This may explain the increase in bone strength when the DMB is modified in a physiological range without necessary changes of BMV and bone microarchitecture. The impact of such modifications on fracture risk and the therapeutic implications of these data remain to be analyzed in the light of previous results reported after treatment with alendronate [7], raloxifene [3], and other antiresorptive agents [9].

\section{Acknowledgments}

The authors thank John Robbins and Keith Condon for scientific discussion and for reviewing the English manuscript and Delphine Farlay, Catherine Simi, and Annie Buffet for their skillful technical assistance.

\section{References}

[1] Balena R, Toolan BC, Shea M, Markatos A, Myers ER, Lee SC, et al. The effects of 2-year treatment with the aminobisphosphonate alendronate on bone metabolism, bone histomorphometry, and bone strength in ovariectomized nonhuman primates. J Clin Invest 1993; 92:2577-86

[2] Boivin G, Baud CA. Microradiographic methods for calcified tissues. Dickson GR, editor. Methods of calcified tissue preparation. Amsterdam: Elsevier; 1984. p. 391-411.

[3] Boivin G, Lips P, Ott SM, Harper KD, Sarkar S, Pinette KV, et al. Contribution of raloxifene and calcium and vitamin D3 supplementation to the increase of the degree of mineralization of bone in postmenopausal women. J Clin Endocrinol Metab 2003;88:4199-205.

[4] Boivin G, Meunier PJ. The degree of mineralization of bone tissue measured by computerized quantitative contact microradiography. Calcif Tissue Int 2002;70:503-11.

[5] Boivin G, Meunier PJ. Effects of bisphosphonates on matrix mineralization. J Musculoskelet Neuronal Interact 2002;2:538-43.

[6] Boivin G, Meunier PJ. Histomorphometric methods applied to bone. Grupe G, Garland AN, editors. Histology of ancient human bone. Berlin: Springer Verlag; 1993. p. 137-56. 
[7] Boivin GY, Chavassieux PM, Santora AC, Yates J, Meunier PJ. Alendronate increases bone strength by increasing the mean degree of mineralization of bone tissue in osteoporotic women. Bone 2000; 27:687-94.

[8] Bouxsein ML. Bone quality: where do we go from here? Osteoporos Int 2003;14(Suppl. 5):118-27.

[9] Burr D. Microdamage and bone strength. Osteoporos Int 2003; 14(Suppl. 5):67-72.

[10] Cendre E, Mitton D, Roux JP, Arlot ME, Duboeuf F, Burt-Pichat B, et al. High-resolution computed tomography for architectural characterization of human lumbar cancellous bone: relationships with histomorphometry and biomechanics. Osteoporos Int 1999;10: $353-60$.

[11] Chavassieux PM, Arlot ME, Reda C, Wei L, Yates AJ, Meunier PJ. Histomorphometric assessment of the long-term effects of alendronate on bone quality and remodeling in patients with osteoporosis. J Clin Invest 1997;100:1475-80.

[12] Ciarelli TE, Fyhrie DP, Parfitt AM. Effects of vertebral bone fragility and bone formation rate on the mineralization levels of cancellous bone from White females. Bone 2003;32:311-5.

[13] Currey JD. The evolution of the mechanical properties of amniote bone. J Biomech 1987;20:1035-44.

[14] Currey JD, Brear K, Zioupos P. The effects of ageing and changes in mineral content in degrading the toughness of human femora. J Biomech 1996;29:257-60.

[15] Hans D, Dargent-Molina P, Schott AM, Sebert JL, Cormier C, Kotzki PO, et al. Ultrasonographic heel measurements to predict hip fracture in elderly women: the EPIDOS prospective study. Lancet 1996;348: $511-4$.

[16] Jensen NC, Madsen LP, Linde F. Topographical distribution of trabecular bone strength in the human os calcanei. J Biomech 1991;24: $49-55$.

[17] Jowsey J. The bone biopsy; 1977. New York: Plenum.

[18] Jowsey J, Kelly PJ, Riggs BL, Bianco AJ, Scholz DA, GershonCohen J. Quantitative microradiographic studies of normal and osteoporotic bone. J Bone Jt Surg Am 1965;47A:785-806.
[19] Linde F, Hvid I, Madsen F. The effect of specimen geometry on the mechanical behaviour of trabecular bone specimens. J Biomech 1992;25:359-68.

[20] Linde F, Sorensen HC. The effect of different storage methods on the mechanical properties of trabecular bone. J Biomech 1993;26: 1249-52.

[21] Meunier PJ, Boivin G. Bone mineral density reflects bone mass but also the degree of mineralization of bone: therapeutic implications. Bone 1997;21:373-7.

[22] Mitton D, Rumelhart C, Hans D, Meunier PJ. The effects of density and test conditions on measured compression and shear strength of cancellous bone from the lumbar vertebrae of ewes. Med Eng Phys 1997; 19:464-74.

[23] Parfitt AM, Drezner MK, Glorieux FH, Kanis JA, Malluche H, Meunier PJ, et al. Bone histomorphometry: standardization of nomenclature, symbols, and units. Report of the ASBMR Histomorphometry Nomenclature Committee. J Bone Miner Res 1987;2: $595-610$

[24] Reid SA, Boyde A. Changes in the mineral density distribution in human bone with age: image analysis using backscattered electrons in the SEM. J Bone Miner Res 1987;2:13-22.

[25] Roschger P, Rinnerthaler S, Yates J, Rodan GA, Fratzl P, Klaushofer $\mathrm{K}$. Alendronate increases degree and uniformity of mineralization in cancellous bone and decreases the porosity in cortical bone of osteoporotic women. Bone 2001;29:185-91.

[26] Turner CH, Burr DB. Basic biomechanical measurements of bone: a tutorial. Bone 1993;14:595-608.

[27] Vogel JM, Wasnich RD, Ross PD. The clinical relevance of calcaneus bone mineral measurements: a review. Bone Miner 1988;5: $35-58$.

[28] Wasnich RD, Ross PD, Heilbrun LK, Vogel JM. Selection of the optimal skeletal site for fracture risk prediction. Clin Ortop 1987; 262-9

[29] Weaver JK, Chalmers J. Cancellous bone: its strength and changes with aging and an evaluation of some methods for measuring its mineral content. J Bone Jt Surg Am 1966;48:289-98. 